\title{
Roman rules? The introduction of board games to Britain and Ireland
}

Mark A. Hall ${ }^{1} \&$ Katherine Forsyth ${ }^{2}$

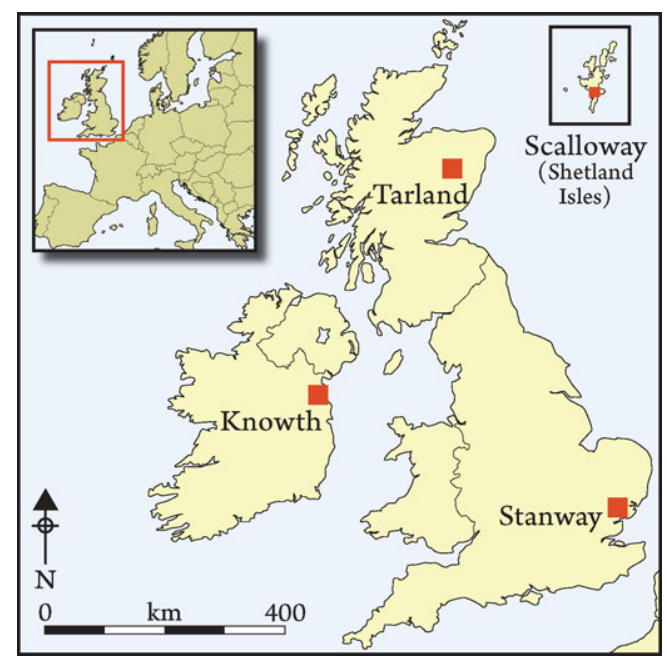

Competitive board games, played on the ground, on the floor or on wooden boards, provide entertainment, distraction and exercise for the mind - it is hard to believe that north-west Europe was ever without them. But the authors here make a strong case that the introduction of such games was among the fruits of Roman contact, along with literacy and wine. In Britain and Ireland games were soon renamed, but belonged like children's jokes to a broad underworld of fastmoving cultural transmission, largely unseen till now.

Keywords: north-west Europe, Britain, Ireland, first millennium AD, Roman, Celtic, board games, ludus latrunculorum, tafl, XII scripta / alea

\section{Introduction}

In recent years Antiquity has addressed the subject of Roman and indigenous or native interaction - a wider process than Romanisation - through board games in the context of the Eastern Empire (Mulvin \& Sidebotham 2004; de Voogt 2010). With this paper we seek to move the debate to the Western Empire, particularly the frontier zone of Britain and Ireland and explore the question of the Roman introduction of board games and their subsequent development by Celtic-speaking peoples.

Literary and archaeological evidence combines to indicate that the playing of board games was a widespread, popular and culturally significant phenomenon among the Celticspeaking peoples of Britain and Ireland in the first millennium AD. Yet little attention has been given to the origin of such games in these islands. Previous writers (e.g. Sterckx

\footnotetext{
1 Perth Museum \& Art Gallery, 78 George Street, Perth PH1 5LB, UK (Email: mahall@pkc.gov.uk)

2 Celtic and Gaelic, University of Glasgow, 3 University Gardens, Glasgow G12 8QQ, UK
} 
1970; Schädler 2007 with circumspection) appear to have taken it for granted or at least allowed that it was possible, that board games were a feature of ancient Celtic society from earliest times. The view presented here, however, is that board games arrived in Britain and Ireland through contact with the Roman world and that they are part of the wider picture of cross-frontier material cultural interaction (Galestin 2010: 64-88).

\section{Moving the pieces around: the role of Rome}

Sterckx (1970) was mistaken in his assumption that the playing of board games is a human universal and that Celtic-speaking peoples are therefore likely to have played them since time immemorial. This idea is rooted in Huizinga's (1950) proposition that play was a universal human given. We root our proposition here in the ideas of Caillois (1958) and Dumazadier (1968) who argue for a culturally contextualised view of play. Board games then are not universal in origin but appear, as far as their Western history is principally concerned, to have a specific origin and dissemination from mid-fourth-millennium BC Egypt and the Fertile Crescent, around the Mediterranean and thence to temperate Europe (Murray 1951: 22638). Cultural contacts with and within the Roman Empire were a particularly important means of diffusion and it was through contacts with Rome that board games entered the Germanic world, reaching far beyond the limes to Scandinavia (as Murray [1951: 230] long ago suggested). Were this not already clear from the archaeological evidence (Whittaker 2006; Sodberg 2007), it would be obvious from the names for such games in the Germanic languages. As Schädler explains (2007: 372) the Germanic name tafl, board game (hence, Anglo-Saxon tafl, Norse tafl and later hnefatafl), derives from Latin tabula (gaming) board or counter. The name travelled yet further north, into Saami culture where the playing of tablut, ultimately, it seems, an Iron Age loan via Norse, was noted by Linnaeus in 1732 and observed among the Saami as late as 1884 (Murray 1913: 445-46; Helmfrid 2000).

The process of dissemination was not one of wholesale borrowing or slavish imitation, but rather a creative indigenous response to stimulus in which games were adapted to local cultural and social contexts. The most recent analysis of tafl in Scandinavia suggests it was derived from Roman imports or gifts of ludus latrunculorum (Sodberg 2007; Whittaker 2006). The Scandinavian variant hnefataft retained ludus latrunculorum's basic mode of capture - by flanking — but changed its two equally matched armies into a king protected by his warband from a larger opposing force of attackers, this innovation perhaps resonating better with the indigenous social and political institution of the comitatus.

The introduction and diffusion of board-gaming throughout temperate Europe is in many ways analogous to the introduction and spread of literacy throughout the same area at approximately the same time. Both followed similar trajectories, in similar social contexts - of elite emulation - and manifest a similar variety in responses to stimulus (see Woolf 1994; Williams 2002; de Hoz 2007). The Norse runic and Irish ogham alphabets are both scripts developed beyond the limes under the influence of Latin literacy, clearly based on the Latin alphabet yet visually very different from their model (Moltke 1985; Harvey 1987; McManus 1991). The link between the earliest evidence of board-gaming and writing is seen in mid-first-century Britain in the cemetery at Stanway which produced an inkwell and several gaming sets (see below), and at Litton Cheney, Dorset where a stylus and a set 


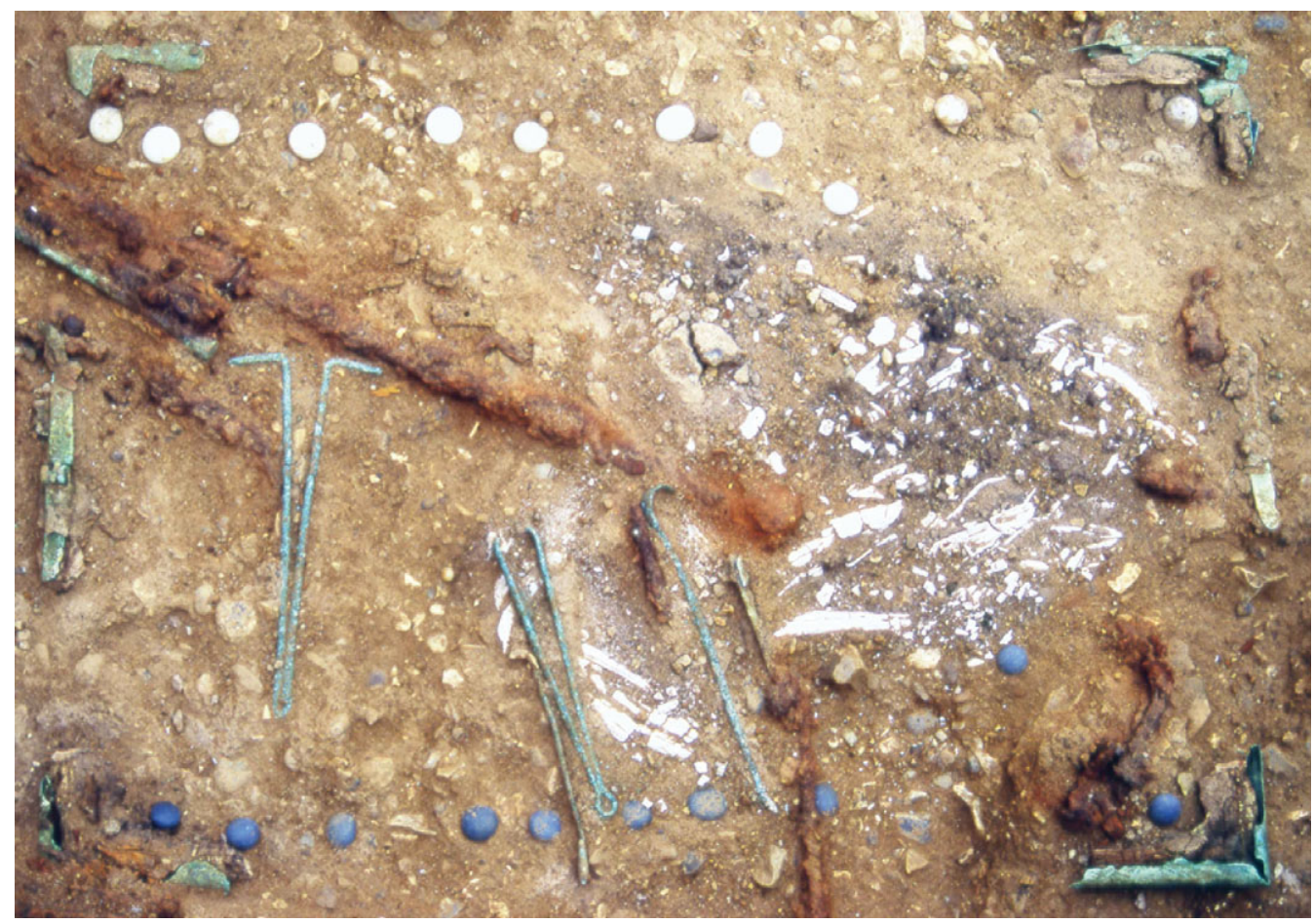

Figure 1. The Doctor's Grave, Stanway, Essex, England. (C) Colchester Archaeology Trust (courtesy of Philip Crummy).

of board game counters were found (Bailey 1967). The adoption and adaptation of Roman board games and writing are part of a much wider process of cultural response manifest in the archaeological record of pre-conquest Britain (Haselgrove 1984; Creighton 2000) and Scandinavia, where we see the innovative adaptation of Roman material culture and practices to new purposes, including, for instance, the ring-fort of Ismantorp as a hybrid of a Roman fort (Andrén 2006) and the reuse of Roman glass vessels in Scandinavian mortuary practices (Ekengren 2006).

\section{From Rome to Stanway and Knowth}

The most important find of early gaming equipment in Britain, and the point of departure for the current study, is the so-called Doctor's Grave from Stanway, Colchester, England (Figure 1). This grave, dated to AD 40-50, contained, in addition to dining equipment, a set of surgical instruments and divining rods, a gaming board with 26 glass counters, apparently laid out on it as if for play. The wood of the board had entirely decayed and all that remained were the metal hinges. From this, and the layout of the pieces, it was possible to reconstruct the size and possible format of the board (Crummy 2007: 352-59; Schädler 2007: 359-75). While it was not possible to say with certainty whether the board was double-sided, this is suggested by the overall size of the board, which follows the rectangular 
form of a Roman XII scripta / alea board, coupled with a low number of pieces (less than 30 ) and the absence of dice, which both suggest use in a game other than XII scripta / alea. Following detailed examination of the Doctor's Grave board, both Crummy (2007: 352-9) and Schädler (2007: 359-75) concluded that, on balance, the board game represented is perhaps best seen not as a known Roman game but as an unknown Celtic one.

In order to explore the question of how Celtic or Roman the earliest insular board games were, it is necessary to survey the earliest material evidence for gaming in Britain and Ireland. The Doctor's Grave board can be related to other pre-Roman wooden boards in south-east Britain, particularly two similar rectangular examples from Grave 117 at King Harry Lane, Verulamium (Stead \& Rigby 1989: 109) and Burial 6 at Baldock (Stead \& Rigby 1986: 68-9), giving a total of three such boards from the territory of the Catuvellauni. To these may be added more fragmentary boards of less certain dimensions from the same territory: from Stanway (a further two, from other burials, Crummy et al. 2007: 126, 186-90), from Verulamium (a further one, Stead \& Rigby 1989: 109-110) and from Welwyn Garden City (one, Stead 1967: 31-6). All these boards are interpretable as "... part of a distinctive British body of artefacts, linked to a specific game popular among a group of Britons in the southeast of the country and with strong connections with the newly Romanised Continent" (Crummy 2007: 359). As Crummy argues "the fact that Roman counters and boards were in the possession of Romanised Britons provides strong evidence in favour of the playing of a Roman game of some sort" (2007: 359). Nonetheless, Schädler prefers to suggest that there is a context of ancient Celtic board games that might explain the Stanway example. His crucial piece of evidence is a find of gaming pieces from Welwyn Garden City which dates to about the final decade of the first century BC that is some 60 years earlier than the Stanway example (Stead 1967: 14-19). This comprises a collection of 24 glass counters made up of four sets of six which Schädler takes as implying an otherwise unknown, non-Roman game for four players, although he himself admits that as such it would be unique as all ancient board games appear to have been for two players. It is, however, far from clear that this material does signal a Celtic game as opposed to a Roman game or a Roman game with Celtic innovations. A possible analogy is an Egyptian race-type game played with two sets of pieces, each set comprising half light pieces and half dark (Murray 1951: 18). Although Schädler provides parallels for glass pieces of similar shape - though not in four sets - from Celtic burials on the continent, all these also have Roman or north Italian/Etruscan associations, with implications of trade and exchange (Stead 1967: 18-19). In further support of his theory of ancient Celtic board games Schädler cites extensive evidence both archaeological and textual but, with one exception, it is all much later in date than the first-century $\mathrm{AD}$ material from Stanway: none of the earliest elements are definitively non-Roman.

The one exception cited by Schädler is the collection of pegged playing pieces and other gaming equipment found in a grave at Knowth, Co. Meath, Ireland (Figure 2). When first excavated this grave was originally dated to no later than the sixth century AD (Eogan 1974: 68-70, 76-80, Burials $10 \& 11$ ) and Schädler discusses the board in terms of this date, alongside other late Roman period continental boards: from Vimose, Denmark ( $c$. $\mathrm{AD}$ 400) and from Leuna, Germany (third century AD). The boards from Vimose and Leuna are double-sided with definite Roman XII scripta / alea layouts on one side. They are plausible as entirely Roman boards gifted or traded into Germanic territories. Since 


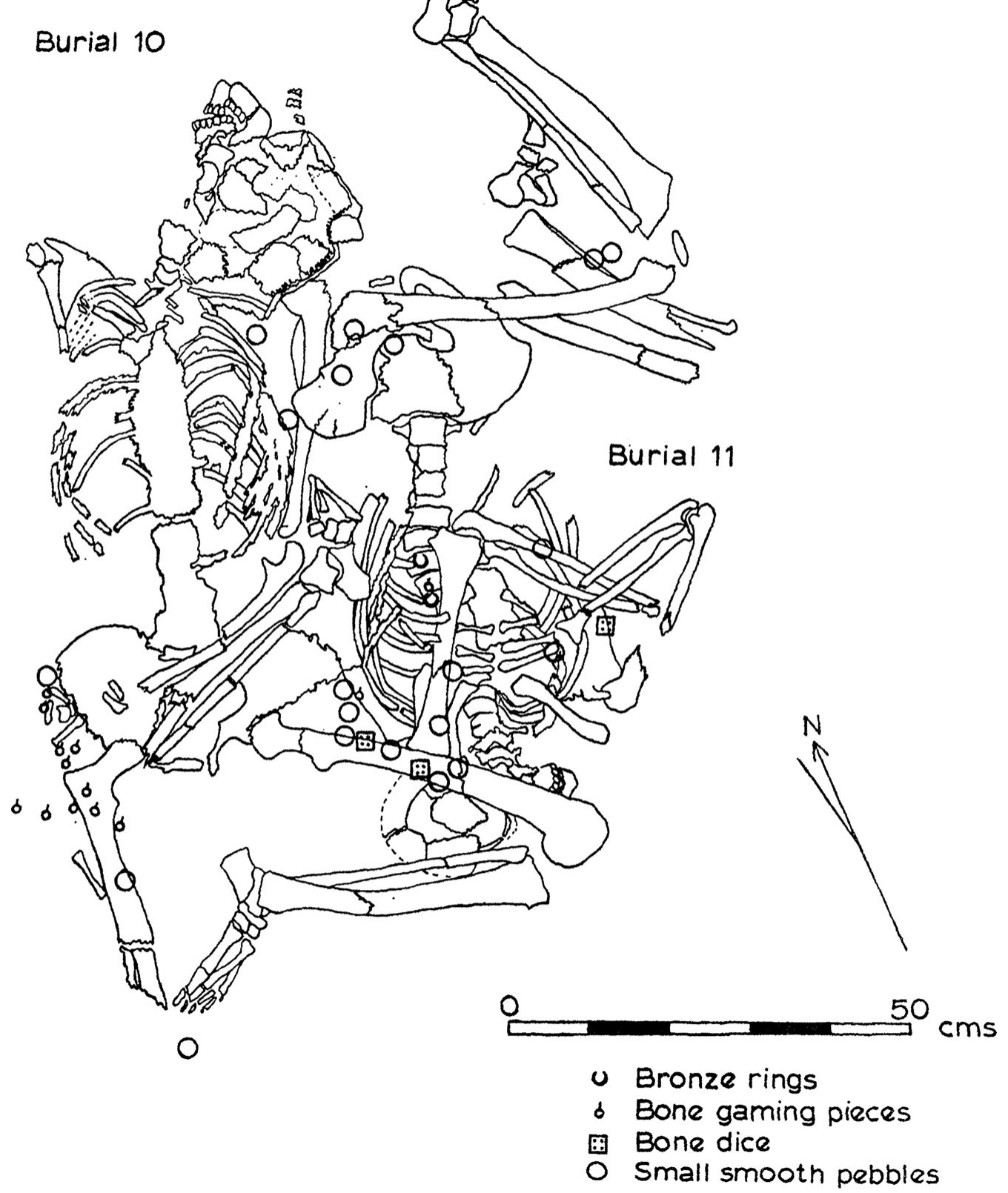

Figure 2. The so-called Gambler's Burial, Knowth, Meath, Ireland. (c) Royal Irish Academy.

Schädler wrote, however, the Knowth burials have been re-evaluated and more precisely dated (Eogan forthcoming, where they are renumbered as Burials 8 and 9). Radiocarbon 
determination of the human bone from the burial in question has produced a date of $1960 \pm 30 \mathrm{BP}$, calibrated at 2 sigma to $40 \mathrm{BC}-\mathrm{AD} 130$ ( $\mathrm{GrN}-15371)$. This gives the burial and its gaming equipment a date very close to that of the Stanway burial. The question, then, is what games were played at Knowth and how do they relate to the Stanway game?

Multiple features mark out the Knowth Gambler's Burial as being of a special nature. It is a double burial of two male relatives probably twins aged around 30 years, who were decapitated prior to burial and buried together, head-to-toe (Wilson et al. forthcoming). Both were placed on their backs, slightly crouched. These inhumation graves at Knowth constitute an innovative burial rite deriving from contemporary mortuary practice in Britain. Other aspects of material culture in the graves also point to links with Britain whether immigrant Britons or Irish seeking to emulate British practices (McGarry forthcoming). (For a wider assessment of Romanisation in Ireland see, for example, Bateson 1973, Freeman 2001, di Martino 2002 and Warner 2007.) Here we focus on the gaming evidence and its possibilities. Skeleton 8 (formerly 10), to the left, had a set of 13 playing pieces — one of them fragmentary - beneath its right hip. Each is a pegged piece of two elements: an irregular, spherical head from which projects a short, pointed peg located in a vertically bored perforation. Allowing for some post-deposition disturbance, the Knowth pegged pieces appear to have been set out in a row, possibly on a wooden board that has not survived. Also found were 21 small, smooth, stone pebbles, presumably gaming pieces, which were grouped in three concentrations: around the right hip and femur of Burial 8 and around the left shoulder and the left hip of Burial 9 (formerly 11). Two of the stones had been artificially coloured blue. The final gaming element is three rectangular bone dice numbered 3-5-4-6, all associated with Burial 9: two with the left shoulder area and one with the right.

The Knowth assemblage is more complex than that from Stanway and apparently more than one game is represented. First there seems to have been a game played on a wooden board using 13 pegged pieces, then another game using stone counters and possibly played on the same board. The dice may have been used in conjunction with the counters or in a third game of their own. That there were three dice, however, may point in the direction of XII scripta / alea. Conventionally XII scripta, using two dice, is the name given to the early imperial version of the game and alea, using three dice, the Late Antique version. The fourth-century find from Qustul included five dice (Schädler 1995, 1998: 17) but full clarity requires an extant board layout. It is striking that the Knowth burial has a single set of 13 pegged-pieces, for there were 13 pieces per side in the Stanway burial. The Knowth board may have been a double-sided one, inspired by a Roman XII scripta / latrunculi double-board, but there is no direct evidence for any board only the fact that the pieces were obviously laid out on something. If it were a double-board then the pegged pieces were perhaps one side in a set of a latrunculi-type game, and the counters and dice for playing something akin to XII scripta. In interpreting gaming sets recovered from funerary contexts it should, however, be borne in mind that what was deposited was a representation of gaming, and that this need not be a complete set for play. In any case, our modern notion of complete sets may be somewhat anachronistic in an age before the commercial marketing of board games, an observation first made by Schädler (2007: 368). 


\section{Wales and the north}

In terms of the Roman archaeological background in Wales there is, as yet, no direct evidence for the playing of latrunculi or variants in Roman/Late Iron Age Wales. The surviving evidence points to gaming more generally, with finds of either counters in a range of materials or counters and dice, and to XII scripta more specifically. The former include examples from the Roman forts at Caerleon, Gwent (Zienkiewicz 1986: 155-6, 202-207; Evans \& Metcalf 1992), Segontium (Caernavon as seen on display in the site museum) and Pen Llystyn (Boon 1968: 80-81), with both in Gwynedd and Brecon Gaer, Powys (Wheeler 1926: 120) and from the native farmstead site of Whitton, South Glamorgan (Price 1981: 159-60; Webster 1981: 147-48). A contentious piece of evidence is the fragment of an opaque, light-blue, plano-convex glass counter of a Roman type common in the first to the fourth century AD from the native hillfort of Dinas Powys (Harden 1963: 186, fig. 9). There are at least two fragments of gaming boards, both from the fort at Holt, Clwyd, one certainly and one probably for XII scripta (Grimes 1930: 128, no. 35; 131, no.12, fig. 60.8). A single lead counter is recorded from Holt but no dice although the diagnostic form of the boards means dice must have been used. Equally the absence of evidence for latrunculi boards from sites in Wales is not necessarily evidence of absence.

The evidence from northern Britain has been considered in detail elsewhere (Hall 2007) and sufficient to say here that it demonstrates that games spread well beyond the imperial frontier, and at an early date. There are numerous finds of gaming pieces from throughout Scotland in a range of materials, glass, stone, bone, reused Roman pottery, and in a variety of shapes, both pegged and plain. As in Wales, however, there are no known Roman boards other than from Roman forts, including Bearsden and Inveralmond. One of the key finds from the far north is the set of Romano-British glass gaming pieces from a second- to third-century grave at Tarland, Aberdeenshire (Figure 3), which signals a clear mixture of indigenous and Roman in a high status, non-Roman burial context.

\section{The linguistic dimension}

Medieval literary sources from Ireland and Wales make frequent mention of board games, the playing of which was clearly an important aspect of daily life among the elite whose interests are reflected in the texts. Amongst several games recorded, special status is accorded to the game of fidchell (Irish) and of gwŷddbwyll (British) (Hellmuth 2006; Minard 2006). The British (i.e. Welsh and Breton) evidence is in general later and more meagre than the Irish, and only general comments can be made regarding the nature of gwŷddbwyll. The Irish evidence, however, is considerably more plentiful and detailed and it is possible to deduce a number of features of fidchell (MacWhite 1947). There is a considerable chronological gap between the gaming sets at Stanway and Knowth and the earliest literary evidence, which is mid-eighth century, in the case of fidchell, and late ninth century for gwyddbwyll. Linguistic analysis of these two names, nonetheless, indicates that they have a much older pedigree. Although superficially so different, the two are, in fact, linguistically cognate: they derive from a common ancestral form. This fact has been recognised by Celticists since the mid-nineteenth century, though its significance has not been adequately probed. The 


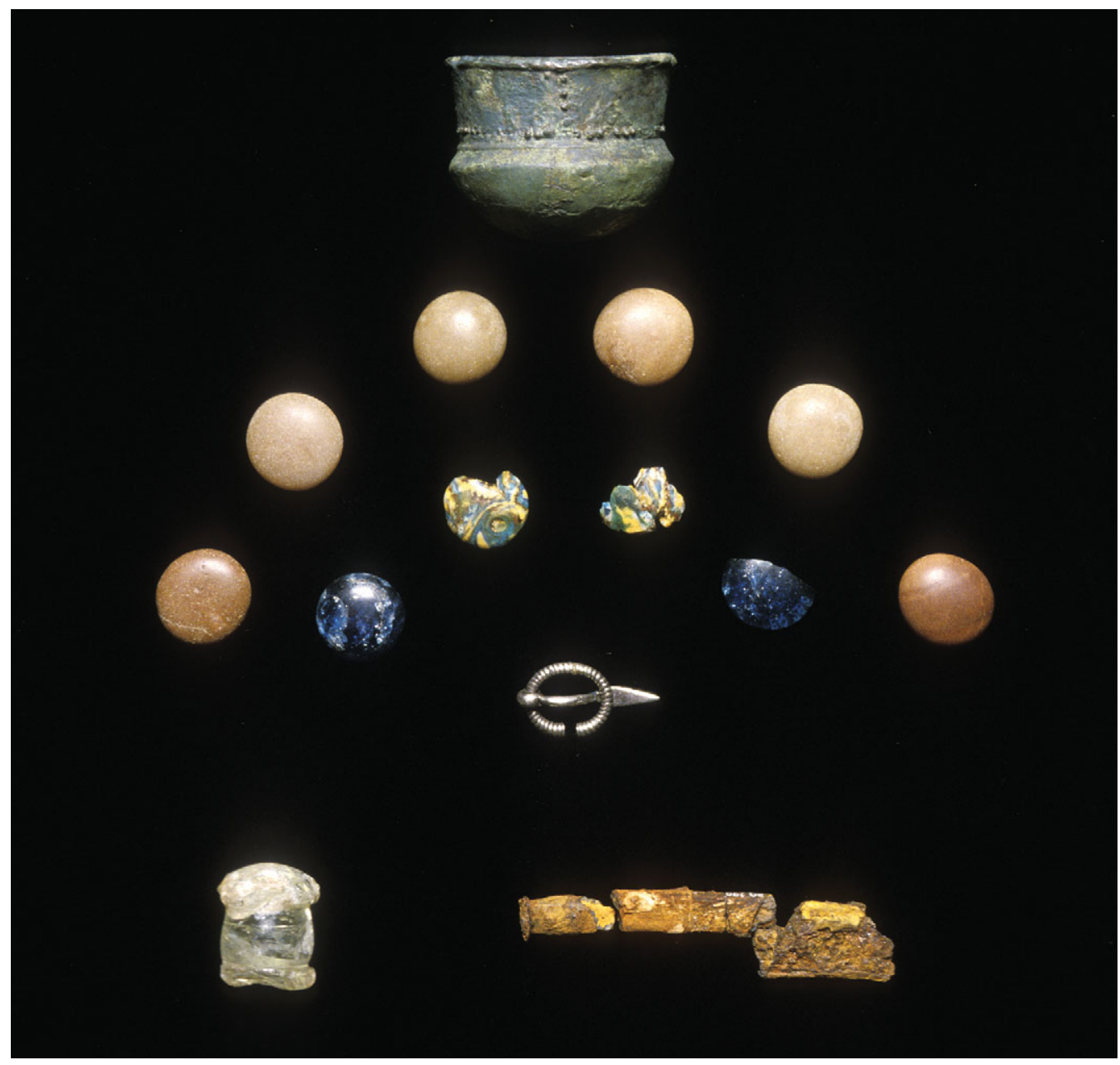

Figure 3. The playing pieces and other finds from the burial at Tarland, Aberdeenshire, Scotland. (c) National Museums Scotland.

forms as they appear in British are Welsh gwyddbwyll $=$ gwydd (wood) + pwyll (sense), and Breton guidpull, guidpoill with the same meaning (Evans \& Fleuriot 1985). In Irish (Gaelic) the form is fidchell $=$ fid $($ wood) $=$ chiall (intelligence). The parent form, though not directly attested, can be reconstructed as Common Celtic * widu- $k^{w}$ eilla $={ }^{*}$ widu-wood + $k^{w}$ eillā understand (Guyonvarc'h 1966: 325-6; Hellmuth 2006). The name, which is not based on any Roman game name, enshrines the principal that this was a game of skill played on a wooden board. The key point here, however, is that these two words must have existed in ancient Irish and ancient British before the major sound changes which utterly transformed these languages in the sixth century $\mathrm{AD}$, marking the shift from Old Celtic to Neo-Celtic (Jackson 1953). Neither word could have been derived from the other after this date, even by translation as the equivalence of the elements would not have been obvious. 
The sixth-century shift from Old Celtic to Neo-Celtic therefore provides a terminus ante quem for the introduction of fidchell and gwyddbwyll to Ireland and Britain.

When it was still assumed that Celtic-speakers had been playing board games since time immemorial, it was readily assumed that ${ }^{*}$ widu- $k^{w}$ eilla $\bar{a}$ belonged to a very early stage of the parent language, Early Iron Age or Late Bronze Age, as indeed many Common Celtic words probably do (Zimmer 2006). While in formal linguistic terms this is indeed possible, it is not a necessary assumption. As argued above, archaeological evidence leads us to suspect that board-gaming was introduced to Ireland from Britain in the first or second century $\mathrm{AD}$. This scenario is entirely consistent with the linguistic evidence: if a game called by the British *widu-k ${ }^{w}$ eilla $\bar{a}$ was adopted in Ireland along with its name at this time, the latter would have evolved according to the regular sound changes into fidchell by the seventh century AD. It should be noted that on the linguistic evidence alone the borrowing could have been in the opposite direction, from Ireland to Britain, but this is not supported by the archaeological evidence.

The question remains, if the British borrowed the idea of board games from the Romans, why did they, in contrast to the Germans, not borrow a Latin word for the game? That they did not is particularly striking given that Latin was widely spoken throughout Roman Britain even in the West (Charles-Edwards 1995) and the British language was receptive of Latin loan-words, as reflected in the very large number of these in medieval Welsh (Jackson 1953: 76-80). The rejection of a Latin name could perhaps be construed as evidence in favour of a very early borrowing, pre-conquest, before widespread exposure to the Latin language, in a context of the ready Celtic assimilation and ownership of Roman material culture redefined as Celtic by certain elite groups. Another possibility is that the game was already called ${ }^{*}$ widu- $k^{w}$ eilla on the continent but that merely pushes the question back to why Gaulish-speakers adopted the game but not the name. Note however, that pre-conquest Britons appear to have borrowed not a Roman game per se but rather the idea of gaming which they realised in their own way, just as the Irish were later to borrow the idea of writing from knowledge of written Latin but chose to invent their own alphabet, ogham.

Celtic avoidance of an imported name for an imported game is seen again at a later period when the Irish adopted the Norse game hnefatafl but gave it an Irish name. Archaeological evidence points to the introduction of hnefatafl to the Celtic world in the ninth and tenth centuries. Detailed references in early Irish literature of the tenth century and later make it clear that a new game was now being played alongside the older and higher status fidchell. This new game is clearly a form of hnefatafl, with its unequal sides and central king piece, though it is never referred to by this name, rather it is known as brandubh: raven black (MacWhite 1947). It is hard to know why Gaels invented a native term rather than adopt the game's Norse name, as they were prepared to accept other Norse borrowings (O Muirithe 2010). It is all the more curious when the Welsh were happy to borrow a Germanic name for their variant of hnefatafl: the Welsh tawlbwrdd is either from Anglo-Saxon tafl + bord, or more probably from Norse taflborð (Brøndsted 1965: 265; see also Lewis 1943).

Celtic literary sources consistently refer to the pieces as men (Irish fir, Welsh gwerin), a metaphor which finds visual expression in two examples from fifth- to seventh-century AD Scotland. Two face-decorated stone cones have been found at the brochs of Scalloway and Mail in Shetland (Figure 4) (Sharples 1998: 172-80; Wilson \& Watson 1998: 174, 


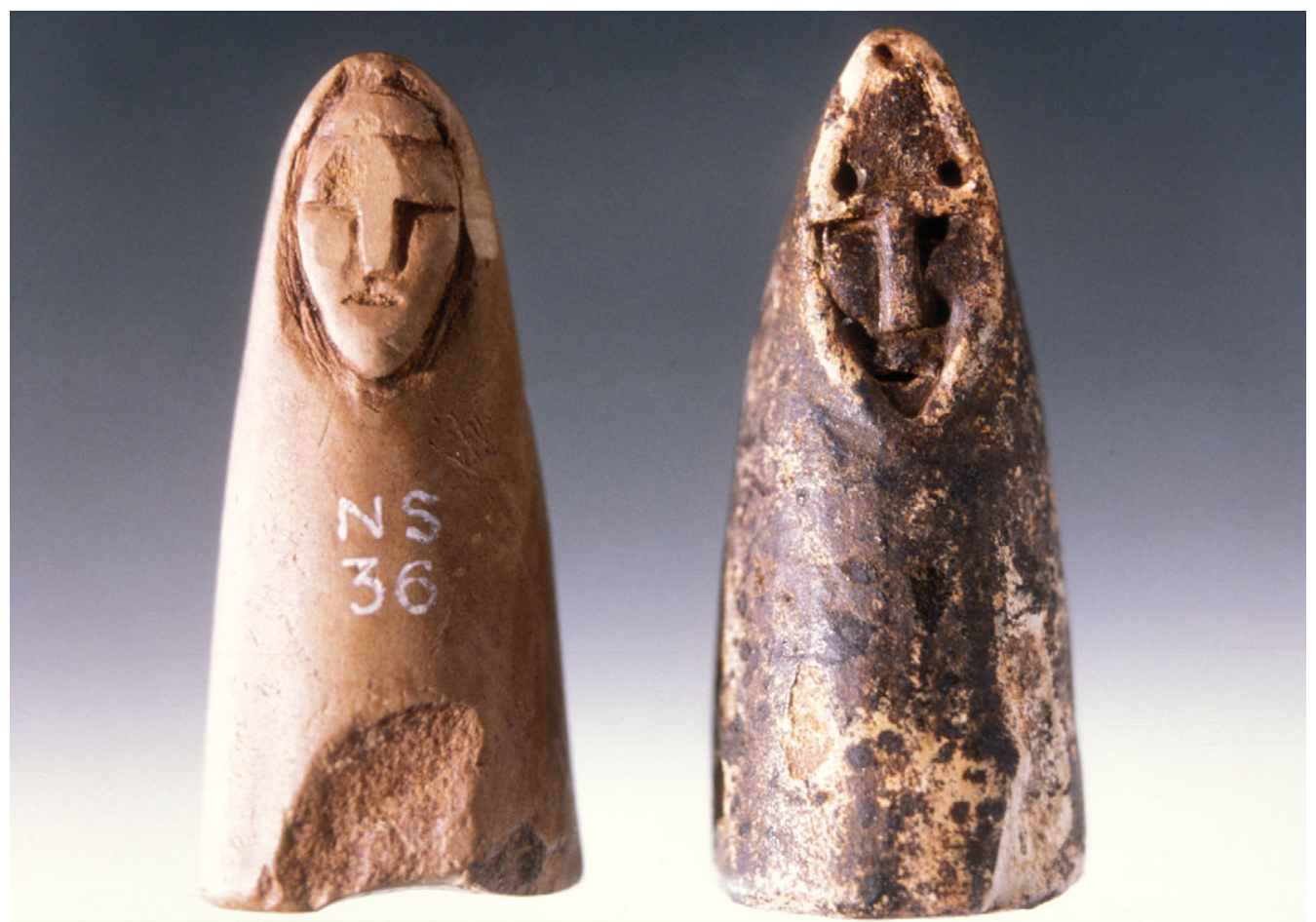

Figure 4. The anthropomorphic playing pieces from Scalloway and Mail, Shetland, Scotland. (C) National Museums Scotland.

fig. 112). The 35 other gaming pieces from the Scalloway assemblage included four further non-decorated stone cones, various counters, flat-bottomed pebbles, phalanges and dice, suggesting a variety of games are represented. A further unprovenanced, face-decorated cone in the Ashmolean Museum, Oxford, is presumed to be Scottish by analogy (Hall 2007). Incidents in Irish literature involving injuries caused by fidchell pieces may imply pieces of a conical rather than a simply pegged form as they are described as becoming embedded in the victim's skull (e.g. Carey 1994: 119). The Shetland evidence strengthens the case previously put forward only hesitantly (Raftery 1983: 229) for interpreting Irish stone cones as gaming pieces. Eleven such cones are known from Irish sites, with several of them securely dated to the fourth and fifth centuries AD (Raftery 1969: 79-82). Although stone cone gaming pieces are unusual on the continent in the Roman period, one parallel can be cited: a ceramic cone of a date from the first to the fourth century AD from among an extensive assemblage of Roman gaming pieces from Barcelona, Spain (de Heredia Bercero 2002: 146-7). It stands out as unusual, however, and certainly contrasts with other gaming assemblages, such as that from the Roman fort of Petavonium, Zamorra, Spain, which comprises fragments of 20 boards for ludus latrunculorum and 470 pieces, all counters (Carretero Vaquero 1998). Two stone cones are known from another of the Knowth burials (Eogan 1968: 365-6), the crouched inhumation of a six-year-old child now dated to 43 cal BC-AD 232 (Wilson et al. forthcoming). On the face of it, cone-shaped playing pieces would appear to be a Celtic innovation rather than a Roman favoured form. 


\section{Conclusion}

The playing of board games works as a cultural transmitter because of the intrinsic appeal of playing games and because of their cultural fluidity. As an arena of performance they can both foster interaction and exchange and sublimate competition. They can be taken readily from one cultural context to another with or without changes of meaning, which do not have to be immediate. At the time in question they were both able to carry Romanitas to the frontiers and beyond and at the same time be amenable to redefinition in the hands of their recipients. Just as the politics of Roman interaction and struggle could be incorporated into the dynamics of XII Scripta: for example see Hall (2007) for the dice-tower from Germany proclaiming 'The Picts defeated ...', so the adaptation of such games by indigenous peoples could function both as a sign of muscular admiration of an enemy and an equal, and as a turning of the tables. The range of games both Roman and African evidenced at the Roman fort of Abu Sha'ar, Egypt (Mulvin \& Sidebotham 2004), implies complex cultural interaction on which it is difficult to call the balance of influences. Even at times of highly tense cultural interaction in our own time the desire to play and its facility to break down barriers is evident. Kayla Williams, a former sergeant in US military intelligence during the American-led occupation of Iraq in the early twenty-first century, observed the interactions consequent on game-playing (2006: 157): "The Kurdish locals also played a game we called 'rock', though this was certainly not its real name. It was a little like checkers. They would draw a grid on the ground and have sides with light rocks or dark rocks. Despite the immense language barrier, the Pathfinders learned to communicate. They learned how to play rock, for instance. Some of the Pathfinders got pretty good at it too, and would win once in a while against the Peshmergas."

This contemporary example throws helpful light on the kind of cultural interaction that can lead to the diffusion of board games in a military context. It also serves to emphasise the sometimes ephemeral nature of gaming equipment which is readily created from found objects and improvised playing surfaces. Moreover, this example shows that a game may be borrowed without its name.

On the basis of the Stanway and Knowth material we propose a scenario whereby the idea of board games reached Britain at the very end of the first century BC from newly conquered Gaul, when gaming was adopted by British elites of the south-east as part of a package of continental and Roman culture, which also included wine-drinking, coinage, literacy and burial with grave goods (Haselgrove 1984; Creighton 2000; see Purcell 1995 for the link between gaming and literacy). A taste for board-gaming may have been one of the things brought home by kings' sons and other British obsides (hostages) sent to Rome for education in Roman ways during this pre-Claudian conquest period (on whom see Creighton 2000: 90-92). The games played in southern Britain may have been fully Roman ones, or local versions. Following the Roman conquest of the region in the mid-first century AD, the playing of Roman and Roman-style games became increasingly widespread, extending well beyond the imperial frontier at an early date. The gaming pieces from Tarland attest to their popularity among the Caledonian elite (Hall 2007). The Knowth evidence indicates that board-gaming had reached Ireland from Britain possibly even before the Roman conquest and, if not, shortly afterwards as part of a broader 
cultural package. The extent to which this was perceived as Roman, rather than British is moot.

\section{Acknowledgements}

We are most grateful to Tiernan McGarry and Jacqueline Wilson for sharing with us their recent work on Knowth and to them and Helen King for permission to refer to it here in advance of publication. Three anonymous referees provided helpful comments some of which we look forward to pursuing in future research.

\section{References}

ANDRÉN, A. 2006. A world of stone: warrior culture, hybridity and Old Norse cosmology, in A. Andrén, K. Jennbert \& C. Raudvere (ed.) Old Norse religion in long-term perspectives: origins, change, and interactions. An international conference in Lund, Sweden, June 3-7, 2004 (Vadgar till Midgard 8): 33-38. Lund: Nordic Academic Press.

BATESON, J.D. 1973. Roman material from Ireland: a re-consideration Proceedings of the Royal Irish Academy 73C: 21-97.

BAILEY, C. 1967. An early Iron Age/Romano-British site at Pins Knoll, Litton Cheney: final report. Proceedings of Dorset Natural History and Archaeological Society 89: 147-59.

Boon, G. 1968. The glass, in A.H.A. Hogg (ed.) Pen Llystyn: a Roman fort and other remains: 178-81. London: Royal Archaeological Institute.

Brønsted, J. 1965. The Vikings. Harmondsworth: Penguin.

CaIllos, R. 1958. Les jeux et les hommes. Paris: Librairie Gallimard.

Carey, J. 1994. Echtrae Nera, in J.T. Koch \& J. Carey (ed.) The Celtic heroic age: literary sources for ancient Celtic Europe and early Ireland and Wales: 115-20. Malden (MA): Celtic Studies Publications.

Carretero Vacquero, S. 1998. El ludus Latrunculorum un juego de estrategia practicado por los équites del Ala II Flavia. Boletin del Seminario de Estudios de Arte y Arqueologia 64: $117-40$.

Charles-Edwards, T. 1995. Language and society among the insular Celts: 400-1000, in M. Green (ed.) The Celtic world: 703-736. London: Routledge.

Creighton, J. 2000. Coins and power in late Iron Age Britain. Cambridge: Cambridge University Press.

Crummy, P. 2007. The gaming board in CF47: the remains as found, possible reconstructions and post-depositional movements, in P. Crummy, S. Benfield, N. Crummy, V. Rigby \& D. Shimmin (ed.) Stanway: an elite burial site at Camulodunum (Britannia monograph series 24): 352-9. London: Society for the Promotion of Roman Studies.
DumAZADIER, J. 1968. Leisure, in D. Sills (ed.) International encyclopaedia of the social sciences: 248-53. New York: MacMillan.

Ekengren, F. 2006. Performing death: the function and meaning of Roman drinking vessels in Scandinavian mortuary practices, in A. Andrén, K. Jennbert \& C. Raudvere (ed.) Old Norse religion in long-term perspectives: origins, change, and interactions. An international conference in Lund, Sweden, June 3-7, 2004 (Vadgar till Midgard 8): 109-113. Lund: Nordic Academic Press.

EogAN, G. 1968. Excavations at Knowth, Co. Meath, 1962-1965. Proceedings of the Royal Irish Academy 66C: 299-400. Dublin: Royal Irish Academy.

- 1974. Report on the excavation of some passage graves, unprotected inhumation burials and a settlement site at Knowth, Co. Meath. Proceedings of the Royal Irish Academy 74C: 11-112.

- Forthcoming. Excavations at Knowth 5: the archaeology of Knowth in the first and second millennia $A D$. Dublin: Royal Irish Academy (with contributions from George Eogan, Madeleine O’Brien, Cathy Johnson and others).

Evans, C. \& L. Fleuriot. 1985. A dictionary of Old Breton: historical and comparative. Toronto: University of Toronto Press.

EVAns, D.R. \& V.M. METCALF. 1992. Roman gates, Caerleon (Oxbow monographs 15). Oxford: Oxbow.

FREEMAN, P. 2001. Ireland and the Classical world. Austin (TX): University of Texas Press.

Galestin, M.C. 2010. Roman artefacts beyond the northern frontier: interpreting the evidence from the Netherlands. European Journal of Archaeology 13(1): 64-88.

Grimes, W.F. 1930. Holt, Denbighshire: the works depot of the Twentieth Legion at Castle Lyons (Cymmrodor 41). London: Society of Cymmrodorion.

GuYonvarc'H, C-J. 1966. Notes d'etymologie et de lexicographie gauloises et celtiques 24. Ogam 18: 311-32.

Hall, M.A. 2007. Playtime in Pictland: the material culture of gaming in early medieval Scotland (Groam House Museum Annual Academic Lecture 2006). Rosemarkie: Groam House Museum. 
Harden, D.B. 1963. Glass, in L. Alcock (ed.) Dinas Powys: an Iron Age, Dark Age and early medieval settlement in Glamorgan: 178-88. Cardiff: Cardiff University Press.

HaRVEY, A. 1987. Early literacy in Ireland: the evidence of ogam. Cambridge Medieval Celtic Studies 14: $1-15$.

Haselgrove, C. 1984. Romanisation before the conquest: Gaulish precedents and British consequences, in T.F.C. Blagg \& A.C. King (ed.) Military and civilian in Roman Britain: cultural relationships in a frontier province (Oxford: British Archaeological Reports British series 136): 5-63. Oxford: British Archaeological Reports.

Hellmuth, P. 2006. Fidchell, in J.T. Koch (ed.) Celtic culture: a historical encyclopedia: 745-46. Santa Barbara (CA): ABC-Clio.

HelmFrid, S. 2000. Hnefatafl, the strategic board game of the Vikings: an overview of rules and variations of the game. Available at: http://hem.bredband.net/ b512479/Hnefatafl_by_Sten_Helmfrid.pdf (accessed February 2010).

de Heredia Bercero, J.B. 2002. From Barcino to Barcinona ( $1^{\text {st }}$ to $7^{\text {th }}$ centuries): the archaeological remains of Placa del Rei in Barcelona. Barcelona: Ajuntament de Barcelona.

DE HOZ, J. 2007. The mediterranean frontier of the Celts and the advent of Celtic writing. Cambrian Medieval Celtic Studies 53/54: 1-22.

HuizInGA, J. 1950. Homo Ludens: a study of the play element in culture. Boston (MA): Beacon Press.

JACKSON, K. 1953. Language and history in early Britain. Edinburgh: Edinburgh University Press.

LEWIS, F. 1943. Gwerin Ffristial: a Thawlbwrdd. The Transactions of the Honourable Society of Cymmrodorion, Session 1941: 185-205.

MACWHite, E. 1947. Early Irish board games. Eigse 5: 25-35. Available at:

http://www.unicorngarden.com/eigse/eigse01.htm (accessed 21 April 2011).

Di Martino, V. 2002. Roman Ireland. Doughcloyne, Wilton, Cork: Collins.

MCGarry, T. Forthcoming. The Knowth Iron Age burials an an Irish and wider context, in G. Eogan (ed.) Excavations at Knowth 5: the archaeology of Knowth in the first and second millennia $A D$. Dublin: Royal Irish Academy.

McManus, D. 1991. A guide to ogam (Maynooth monographs 4). Maynooth: An Sagart.

Minard, A. 2006. Gwyddbwyll, in J.T. Koch (ed.) Celtic culture: a historical encyclopedia: 866 . Santa Barbara (CA): ABC-Clio.

MoltKe, E. 1985. Runes and their origin: Denmark and elsewhere. Copenhagen: National Museum of Denmark.
Mulvin, L. \& S.E. Sidebotham. 2004. Roman game boards from Abu Sha'ar (Red Sea Coast, Egypt). Antiquity 78: 602-617.

Murray, H.J.R. 1913. A history of chess. Oxford: Clarendon Press.

- 1951. A history of board games other than chess. Oxford: Clarendon Press.

O Muirithe, D. 2010. From the Viking word-hoard: a dictionary of Scandinavian words in the languages of Britain and Ireland. Dublin: Four Courts Press.

PrICE, J. 1981. The glass, in M.G. Jarrett \& S. Wrathmell (ed.) Whitton: an Iron Age and Roman farmstead in South Glamorgan: 148-62. Cardiff: University of Wales Press.

PurCell, N. 1995. Literate games: Roman urban society and the game of alea. Past and Present 147: 3-37.

Raftery, B. 1969. Freestone Hill, Co. Kilkenny: an Iron Age hillfort and Bronze Age cairn excavation Proceedings of the Royal Irish Academy 68C: 1-108.

- 1983. A catalogue of Irish Iron Age antiquities (Veroöffentlichungen des vorgeschichtlichen Seminars Marburg 1). Marburg: Vorgeschichtliches Seminar der Philipps Universität.

SCHÄDLER, U. 1995. 12 scripta, alea, tabula: new evidence for the Roman history of backgammon, in A.J. de Voogt (ed.) New approaches to board games research: Asian origins and future perspectives (International Institute for Asian Studies Working Papers Series 3): 64-72. Leiden: IIAS.

- 1998. Mancala in Roman Asia Minor? Board Games Studies 1: 10-25. Available at: http://www.boardgamestudies.info/pdf/issue1/ BGS1-complete.pdf (accessed August 2011).

- 2007. The Doctor's Grave: new light on the history of ancient board games, in P. Crummy, S. Benfield, N. Crummy, V. Rigby \& D. Shimmin (ed.) Stanway: an elite burial site at Camulodunum (Britannia Monograph 24): 359-75. London: Society for the Promotion of Roman Studies.

SHARPLES, N.M. 1998. Scalloway: a broch, late Iron Age settlement and medieval cemetery in Shetland (Oxbow monograph 82): 174-5. Oxford: Oxbow.

SøDBERG, B. 2007. Pastimes or serious business? Norwegian graves with gaming objects $c$. 200-1000 $\mathrm{AD}$, in B. Hardh, K. Jennberht \& D. Olausson (ed.) On the road: studies in honour of Lars Larsson (Acta Archaeologia Lundensia 26): 265-69. Stockholm: Almqvist \& Wiksell International.

STEAD, I.M. 1967. A La Tène III burial at Welwyn Garden City. Archaeologia 101: 1-62.

STEAD, I.M. \& V. RigBY. 1986. Baldock: the excavation of a Roman and post-Roman settlement 1968-72 (Britannia Monograph 7). London: Society for the Promotion of Roman Studies. 
- 1989. Verulamium: the King Harry Lane site (Historic Buildings and Monuments Commission, Archaeological Report 12). London: English Heritage.

STERCKX, C. 1970. Les jeux de damiers celtiques. Annales de Bretagne 77: 599-609.

DE VoogT, A. 2010. Mancala players at Palmyra. Antiquity 84: 1055-1066.

WARNER, R.B. 2007. Did the Romans invade Ireland? Available at: www.marsatqueens.co.uk/seminar-three.html (accessed 7 October 2008).

WeBSTER, J. 1981. Pottery spindle whorls and counters, in M.G. Jarrett \& S. Wrathmell (ed.) Whitton: an Iron Age and Roman farmstead in South Glamorgan: 147-8. Cardiff: University of Wales Press.

WHEELER, R.E.M. 1926. The Roman fort near Brecon (Cymmrodor 37). London: Cymmrodorion Society.

WHITAKER, H. 2006. Game boards and gaming pieces in the northern European Iron Age (Nordlit. Tidskrift for kultur og litteratur 24): 103-112. Available at: http://www.uit.no/getfile.php?PageId=977\&amp; Field $=877$ (accessed 5 August 2008)

Williams, J. 2002. Coin inscriptions and the origin of writing in pre-Roman Britain. The British Numismatic Journal 71: 1-17.
WiLliams, K. 2006. Love my rifle more than you: young and female in the US army. London: Phoenix.

Wilson, G. \& P.M. Watson. 1998. Playing pieces, in N.M. Sharples, Scalloway: a broch, late Iron Age Settlement and medieval cemetery in Shetland (Oxbow monograph 82): 174-5. Oxford: Oxbow.

Wilson, J.C., H. Usborne, C. TAYlor, P. Ditchfield \& A.W.G. PIKE. Forthcoming. Strontium and oxygen isotope analysis on Iron Age and early historic burials around the Great Mound at Knowth, Co. Meath. Appendix 5, in G. Eogan (ed.) Excavations at Knowth 5: the archaeology of Knowth in the first and second millennia AD. Dublin: Royal Irish Academy.

WoOLF, G. 1994. Power and the spread of writing in the west, in A. Bowman \& G. Woolf (ed.) Literacy and power in the ancient world: 84-98. Cambridge: Cambridge University Press.

ZIENKIEWICZ, J.D. 1986. The legionary fortress baths at Caerleon. Volume 2: the finds. Cardiff: National Museum of Wales.

Zimmer, S. 2006. Proto-Celtic, in J. T. Koch (ed.) Celtic culture: a historical encyclopedia: 1464-66. Santa Barbara (CA): ABC-Clio. 